\title{
Pain Amplification Syndrome
}

National Cancer Institute

\section{Source}

National Cancer Institute. Pain Amplification Syndrome. NCI Thesaurus. Code C119048.

A condition in which the nerves register normal stimuli (lack of tissue injury) as pain, resulting in feelings of intense pain with even minor sensory input. 